Małgorzata Budzowska (D) http://orcid.org/0000-0002-1953-2088

Uniwersytet Łódzki

e-mail: malgorzata.budzowska@uni.lodz.pl

Otrzymano/Received: 28.02.2020

Zaakceptowano/Accepted: 30.03.2020

Opublikowano/Published: 18.05.2020

\title{
Paradygmat arystotelesowski w zarządzaniu teatrem - casus Macieja Nowaka
}

Abstract

The Aristotelian Paradigm in Theatre Management - a Case Study of Maciej Nowak

Models of theatre management in Poland are a widely discussed issue, given the fact that no satisfactory role model of a theatre leader and manager has yet been developed. This paper proposes a critical view of one of the most famous directorial tenures in Polish theatre, i.e. the management of Maciej Nowak at the Wybrzeże Theatre in Gdańsk (2000-2006). In this context, it aims to identify the most urgent problems related to theatre management and to answer the question of how they can be prevented. Maciej Nowak's managerial practices are analysed in the context of the management paradigms developed by Peter Bendixen [2008] and in relation to the three-part (artistpriest-manager) leadership model proposed by Mary Jo Hatch, Monika Kostera, and Andrzej K. Koźmiński [2010].

Keywords: management paradigms, theatre management, Maciej Nowak, Wybrzeże Theatre in Gdańsk

Słowa kluczowe: paradygmaty zarządcze, zarządzanie teatrem, Maciej Nowak, Teatr Wybrzeże w Gdańsku

\section{Wprowadzenie}

Wypracowywanie najbardziej efektywnych modeli zarządzania w teatrach publicznych w Polsce nadal pozostaje in statu nascendi, wywołując liczne spory środowiskowe i polityczne. Publiczne instytucje kultury wymagają bowiem dalece odmiennego 
podejścia zarządczego niż to reprezentowane w zarządzaniu projektami czysto biznesowymi. Zasadniczym obszarem kontrowersji jest relacja między kulturą a ekonomią i wynikające z niej propozycje modeli zarządczych w instytucjach kultury, które często nie uwzględniają autotelicznej wartości kultury, wymykającej się miernikom ekonomicznym. Teatr jako instytucja kultury, a dokładniej - instytucja artystyczna, produkuje kompatybilnie dobra i usługi: „W teatrze mamy do czynienia z tworzeniem dzieła (inscenizacją utworu dramatycznego lub tekstu dla teatru) oraz z przekazaniem tego dzieła odbiorcom w postaci widowiska teatralnego, a więc z usługą" [Trzeciak 2011:9]. Co istotne, tak stworzone dobro (spektakl teatralny) ma charakter nieuprzedmiotowiony, stanowi dzieło o naturze otwartej i efemerycznej, co więcej, przekazywane jest odbiorcy w usłudze o równie zmiennym charakterze, zależnym od okoliczności i warunków każdego z pokazów. Zarządzanie produkcją tak zdefiniowanych dóbr i usług, w którą zaangażowany jest zespół współpracowników o zróżnicowanych kompetencjach, wymaga wszechstronnych umiejętności i świadomości uczestnictwa w projekcie samowartościującym.

Celem projektu teatralnego jest przeżycie estetyczne zarówno twórców, jak i odbiorców, produkowane nieustannie od momentu rozpoczęcia prób i wznawiane w każdorazowym przebiegu $\mathrm{z}$ udziałem widzów, i jako takie stanowi samo w sobie wartość dodaną. Sformułowanie jednorodnego, efektywnego modelu zarządczego dla podmiotu produkującego takie dobra i usługi, jakim jest teatr, wydaje się wobec tego zadaniem skomplikowanym. Specyfika działalności artystycznej wymaga właściwego podejścia menedżerskiego, wypracowywanego w ścisłym związku z profilem i statusem prawnym danego teatru. Wydaje się, że dyrektor teatru publicznego, jako menedżer instytucji publicznej, powinien reprezentować tak wypracowany konglomerat umiejętności menedżersko-artystycznych, by stał się efektywnym przywódcą projektu teatralnego finansowanego z pieniędzy publicznych. Celem niniejszego artykułu jest próba krytycznego oglądu tak rozumianego modelu zarządczego, rozważanego przez pryzmat działalności Macieja Nowaka, jednego z głównych moderatorów polskiego życia teatralnego, w czasie jego dyrektorskiej kadencji w Teatrze Wybrzeże w Gdańsku. Zasadniczym paradygmatem zarządczym, w którym omówiona zostanie działalność Nowaka, będzie model zwany arystotelesowskim, zaproponowany przez Petera Bendixena [2008], wsparty teorią wzajemności trzech modeli przywódczych (menedżer, artysta, kapłan) [Hatch, Kostera, Koźmiński 2010]. Ponieważ dyrekcja Nowaka w Teatrze Wybrzeże zakończyła się w atmosferze skandalu i do dziś podlega skrajnym ocenom, bezpośrednio odzwierciedlającym trudną relację między kulturą a ekonomią, niniejszy artykuł ma za zadanie krytyczną obserwację implementacji paradygmatu arystotelesowskiego w zarządzaniu teatrem, ze wskazaniem jego rozpoznanych wad, ale również z omówieniem wszelkich okoliczności zewnętrznych, ograniczających, a czasami wręcz uniemożliwiających jego realizację.

$\mathrm{Z}$ metodologicznego punktu widzenia artykuł opiera się na dostępnych materiałach prasowych oraz artykułach branżowych dotyczących dyrekcji Nowaka 
w Teatrze Wybrzeże, ze szczególnym uwzględnieniem tekstów analizujących sytuację zwolnienia Nowaka z funkcji dyrektora Wybrzeża. Kontrowersyjna decyzja marszałka województwa pomorskiego o usunięciu go ze stanowiska wiązała się bowiem z oceną jego działalności zarządczej w teatrze. Temat nie doczekał się jeszcze żadnego opracowania ściśle naukowego, stąd niniejszy artykuł jest pierwszą propozycją oglądu tej sytuacji z perspektywy modeli zarządczych. Jako studium przypadku analiza stylu zarządzania Nowaka w Wybrzeżu, przeprowadzona w odniesieniu do paradygmatów zarządczych, miałaby największą wartość, gdyby główny aktor tej sytuacji, czyli Nowak, zgodził się na rozmową z autorką o swojej dyrektorskiej kadencji w Wybrzeżu. Niestety, mimo wstępnej zgody Nowak wycofał się z kontaktu w tej sprawie, nie podając uzasadnienia. Dlatego, jednym z głównych źródeł cytowanych w artykule jest wywiad rzeka, jakiego udzielił on Oldze Święcickiej i który został opublikowany w formie książki pt. Mnie nie ma. Perspektywa subiektywnego oglądu sytuacji zarządczej w teatrze prezentowana w tym wywiadzie przez Nowaka w połączeniu z opiniami i komentarzami obserwatorów z zewnątrz - dziennikarzy, krytyków teatralnych i badaczy - stanowi główną oś analizy w artykule. Natomiast ramę teoretyczną studium przypadku dyrekcji Nowaka w Teatrze Wybrzeże tworzy wspomniana już koncepcja paradygmatu arystotelesowskiego Bendixena oraz kapłańsko-artystowsko-menedżerski model przywódczy.

\section{Paradygomat arystotelesowski i platoński w zarządzaniu kulturą}

Rozważając skomplikowaną i trudną do jednoznacznego zdefiniowania specyfikę zarządzania podmiotami produkującymi dobra i usługi kulturalne, Bendixen [2008] podjął próbę klasyfikacji modeli zarządczych w zarządzaniu kulturą na podstawie paradygmatów filozoficznych wywodzących się od dwóch najwybitniejszych myślicieli starożytnych, Platona i Arystotelesa ${ }^{1}$. Bendixen przejął schemat Arystotelesowskiej koncepcji entelechii i zderzył go z Platońskim racjonalizmem, wypracowując w ten sposób modele zarządcze odzwierciedlające konflikt istniejący między kulturą a ekonomią. W ujęciu Arystotelesowskim każdy byt posiada swoją entelechię, czyli celowość, która stanowi o pierwszym poruszeniu wprawiającym w ruch istnienie tego bytu [Arystoteles 1998, 412a: 19-22]. Celowa zasada bytu Arystotelesa łączy się zatem bezpośrednio $\mathrm{z}$ ideą autoteliczności kultury, a sztuki w szczególności. W takim ujęciu działalność artystyczna rozumiana jest jako akt samowartościujący i autoteliczny, niepoddający się ocenom za pomocą mierników ekonomicznych. Zarządzanie tak rozumianym procesem artystycznym zawsze będzie spełniało rolę podrzędną:

1 Szczegółowe omówienie obu paradygmatów w odwołaniu do obszernej literatury przedmiotu proponują Jerzy Łysiński [2012] i Joanna Kasza [2017]. 
W ujęciu arystotelesowskim zarządzanie kulturą może jedynie spełniać funkcję wspierającą. Służebny charakter zarządzania kulturą znajduje się poza właściwym artystycznym procesem kreacji w obszarach, w których włączenie sztuki do rzeczywistości otaczającego ją społeczeństwa staje się nieodzowne; dotyczy to zasobów materialnych - pieniędzy, pomieszczeń, kontaktów z publicznością, obowiązków administracyjnych [Bendixen 2008: 224-225].

W odniesieniu do Platońskiego intelektualizmu, Bendixen biegunowo ustanawia paradygmat platoński, propagujący instrumentalny profesjonalizm. Grecki filozof idealistycznie wierzył w siłę rozumu ludzkiego i jego zdolność do gromadzenia wiedzy i kierowania ludzkimi działaniami. Zgromadzona wiedza miała stanowić wystarczające zabezpieczenie do podejmowania właściwych decyzji [Platon 1958, 351B-357E]. W takim ujęciu zarządzanie kulturą zostaje zrównane z zarządzaniem przedsiębiorstwem, gdzie plany produkcyjne realizowane są na podstawie kalkulacji ekonomicznej. Nietrudno zauważyć, że proces artystyczny nigdy w pełni nie poddaje się takim instrumentalnym rachunkom, głównie z powodu swojej oryginalności i nieprzewidywalności. Żadna zgromadzona wiedza nie potrafi stuprocentowo przewidzieć i obliczyć za pomocą mierników ekonomicznych efektu działania artystycznego, ponieważ z samej swej natury zakłada ono „coś nowego”. Co więcej, z uwagi na fakt, iż proces produkcji spektaklu angażuje zespół ludzi i czynnik ludzki ma w nim znaczenie nadrzędne, produkcja może podlegać różnym emocjonalnym wahaniom, z zerwaniem prób włącznie. Stochastyczny charakter procesu twórczego uniemożliwia jego pełną kontrolę ekonomiczną, dlatego paradygmat platoński, usiłujący hegemonizować menedżeryzm w kulturze, skazany jest na porażkę.

\section{Dyrektor przychodzi...}

Działalność dyrektorska Nowaka w Teatrze Wybrzeże w Gdańsku (w latach 20002006) stanowi emblematyczny przykład kontrowersji w obszarze zmian zachodzących w teatrze polskim na początku XXI wieku. Ze względu na to iż Nowak prowadził i nadal prowadzi wiele działań w obszarze kultury teatralnej, sam nie będąc artystą, a raczej kimś, kto artystyczny ferment inspiruje, organizuje i promuje ${ }^{2}$, jego aktywność można uznać za pionierską próbę formułowania różnych ścieżek rozwoju polskiego teatru współczesnego, co słusznie zauważył Łukasz Drewniak:

Nowak jako człowiek z konkretną biografią i poglądami, brawurowy organizator artystycznego zamętu to postać barwna, choć niekoniecznie jednoznaczna. Tabela z aktywami i pasywami

2 Nowak pełnił wcześniej liczne funkcje dyrektorskie w instytucjach kultury, ale nie w teatrze. Ich szczegółową listę podaje Jan Ciechowicz [2019]. 
Nowaka, od 15 lat jednego z głównych rozdających polskiego życia teatralnego, nie przypadkiem pokrywa się z listą zdobyczy i klęsk rodzimego środowiska teatralnego [Drewniak 2005].

Obserwacje Drewniaka dotyczą działalności Nowaka przed objęciem stanowiska w Wybrzeżu oraz podczas jego dyrektorskiej kadencji w tym teatrze, będącej ówczesnym zwieńczeniem brawurowej ścieżki krytyka teatralnego, który stał się dyrektorem teatru. Wydaje się, że właśnie taki układ przejścia, z fotela widza krytyka na fotel dyrektora, z branżowej widowni za kulisy, ma w wypadku stanowiska dyrektora teatru znaczenie kapitalne. Sam Nowak autorefleksyjnie, jeszcze w czasie swojej dyrektorskiej kadencji, zauważał istotową zmianę swojej perspektywy oglądu działalności teatru:

Dokąd siedziałem po tamtej stronie teatralnego lustra, w wygodnym fotelu krytyka, wiedziałem wszystko. Co jest dobre, a co nie, który reżyser umie pracować z aktorami, a któremu się to nie udaje, kto ma talent, a komu go nie staje? Dzisiaj, odkąd przeszedłem na drugą stronę rampy, swobodnie czuję się głównie w restauracji (...). Jeśli chodzi o spektakle, jakoś niespodziewanie straciłem rezon. Nie potrafię już w dwóch złośliwych bon motach podsumować całego przedstawienia, jednym zgrabnym określeniem przekreślić wielomiesięczną pracę aktora, reżysera, scenografa. (...) Ja w każdym razie wiem jedno: o ile nie mam recepty na dobry spektakl, to wyczuwam w miarę trafnie, gdzie czaić się może dobry teatr. Teatr, na którego afiszu znajdziecie spektakle i dobre, i złe, teatr, którego losy mogą być dramatycznie powikłane, teatr budzący skrajne emocje widzów i krytyki, teatr żywy [Nowak 2004].

W powyższej wypowiedzi przebijają dwie istotne refleksje. Jedna dotyczy właśnie owej zmiany perspektywy oglądu procesu twórczego produkcji spektaklu: widz krytyk, poddający ocenie produkt finalny, jakim jest spektakl, skupia się wyłącznie na efekcie pracy artystycznej, bez uważnego wglądu w sam proces twórczy, podczas gdy dyrektor teatru, który planuje, obserwuje i nadzoruje cały proces tworzenia spektaklu, w oczywisty sposób ogląda i ocenia efekt finalny przez pryzmat wielomiesięcznych zmagań zespołu, którego jest instytucjonalnym protektorem. Przejście na drugą stronę rampy jest $\mathrm{w}$ tym wypadku doświadczeniem formującym specyficzny model dyrektorski w teatrze. Z tym też wiąże się druga refleksja Nowaka, która dotyczy jego recepty na dobry teatr: ma to być teatr „żywy”, czyli taki, który pozostaje w nieustannym napięciu poszukiwawczym i nie daje się wcisnąć w sztywne ramy repertuarowej bańki dla wybranej publiczności.

„Teatr budzący skrajne emocje widzów i krytyki” to oczywiście projekt wysokiego ryzyka ekonomicznego, ale i artystycznego. Poszukiwanie nowych estetyk teatralnych wiązało się $\mathrm{w}$ przypadku Nowaka $\mathrm{z}$ zatrudnianiem twórców mało znanych, którzy tworzyli nową jakość w teatrze, co do której nikt nie potrafił przewidzieć, jak zostanie przyjęta przez krytykę i publiczność. Rozważając sytuację przyjścia Nowaka do Wybrzeża z tak sformułowanym planem działania, należy wskazać dwie 
przestrzenie potencjalnego konfliktu, które napotkał nowy dyrektor, a które można definiować w wymiarze obiektywnym jako dwa obszary stanowiące największe wyzwanie zarządcze dla dyrektora teatru. Jest to przestrzeń współpracy z zespołem artystycznym oraz przestrzeń mniej lub bardziej formalnych kontaktów z lokalnym środowiskiem polityczno-biznesowym.

W pierwszym krytycznym obszarze chodzi o wypracowanie systemu twórczej i obopólnie akceptowanej współpracy dyrektora i zespołu artystycznego. W paradygmacie arystotelesowskim zespół artystyczny stanowi aksjologicznie dział instytucji stojący na szczycie, podczas gdy zarówno dyrektor teatru, jak i podlegające mu działy techniczne i administracyjne pełnią wyłącznie funkcje pomocnicze wobec działań artystycznych. Wynika to z podkreślanego w modelu arystotelesowskim prymatu treści nad formą [Bendixen 2008], a treścią działalności teatru jest sztuka, podczas gdy instytucja formalna ją organizująca ma wobec niej charakter wspomagający i służebny. Sformułowanie zasad twórczej współpracy dyrektora, jako przedstawiciela działów wspomagających proces artystyczny, z zespołem artystów wydaje się zatem kluczowe. Nie bez znaczenia pozostają w tym kontekście typ osobowości nowego dyrektora oraz jego reputacja, które narzucają zespołowi wstępne wyobrażenia o nowym przełożonym. Nowak, ze swoją sławą bon vivanta, acz z silnym potencjałem krytycznym, mógł budzić niepokój w zespole Wybrzeża, ale jednocześnie dawać nadzieję na twórczy rozwój i artystyczną świeżość. Co istotne, to aktorzy Teatru Wybrzeże mieli przyjść do Nowaka, wówczas dyrektora Nadbałtyckiego Centrum Kultury, z prośbą, by objął to stanowisko. Sam Nowak tak wspomina swoje przyjście do Wybrzeża:

Kiedy pojawia się postać dominująca, odbiera przestrzeń innym. Dlatego na samym początku musiałem wymyślić strategię przetrwania. Zdecydowałem, że nie będę zapraszał gwiazd, których wielkość czasem współtworzyłem jako recenzent. Postawiłem na stworzenie własnej ekipy [Dobrowolski 2018].

Tę poniekąd optymistyczną obserwację warto zestawić z inną wypowiedzią Nowaka, obrazującą trudności w realizacji tak sformułowanej strategii:

Kiedy starałem się o stanowisko dyrektora w roku 2000, miałem poczucie, że wszystkie atuty mam w ręku. Tymczasem kiedy już zostałem powołany, odczułem powściągliwość wielu osób. (...) Okazało się, że artyści, których ceniłem jako recenzent, zaczynają postrzegać mnie jak konkurenta [Dobrowolski 2018].

Kwestia osobistej wyrazistości dyrektora teatru, który zderza się w swojej pracy z grupą artystów, z których każdy jeden ambicjonalnie dąży do wykreowania własnego artystycznego emploi, to zagadnienie wpisujące się w problem modelu zarządczego w teatrze. W tym kontekście Rafał Maciąg wskazuje na specyfikę zespołu 
artystycznego teatru, którego członkowie kierują się głównie swoimi ambicjami dotyczącymi ich wizji artystycznych, bez większej uważności dla racjonalnych (w tym ekonomicznych) przesłanek dla realizacji tychże:

Także w obrębie samych zespołów osobiste cele aktorów i reżyserów, domyślnie skierowane ku jednemu, najogólniejszemu, łączącemu ich zadaniu, jakim jest stworzenie spektaklu teatralnego, rozbiegają się w różnych kierunkach, silnie motywowane przez ambicje, wewnętrzne przekonania czy wizje, które z najwyższą trudnością poddają się racjonalnej argumentacji [Maciąg 2008: 45].

Nowak, promujący dominujący w Polsce teatr reżyserski, w którym reżyser staje się głównym decydentem w projekcie, jednocześnie diagnozuje trudności współpracy dyrektora z zapraszanymi do konkretnych projektów reżyserami, w czym ujawnia się też słabość strategii sprowadzania twórców spoza stałego zespołu teatru:

W trakcie prób trzeba ścierać się z aroganckimi reżyserami, żądającymi wszystkiego i odgrywającymi cały performance współzawodnictwa z dyrektorem. Oczywiście to jest gra o dusze aktorów, ale trudno zachować dystans. Potem następują próby generalne i nagle [reżyser - M.B.] traci tę bezczelną pewność, którą miał wcześniej podczas prób. (...) Wtedy odpowiedzialność przechodzi na mnie. Reżyser zaraz wyjedzie, a ja zostaję z sukcesem, ale często także z pasztetem. Nie mogę się jednak zdradzić z żadnymi wątpliwościami, bo przecież tak naprawdę to ja jestem tutaj dowódcą i muszę w aktorach i wszystkich ludziach w teatrze podtrzymywać morale [Święcicka 2015: 149].

W kontekście konstruowania zespołu artystycznego Nowak zainicjował nowy, z czasem gwałtownie narastający, konflikt środowiskowy, ponieważ oparł się na reżyserskich talentach sprowadzanych z zewnątrz, czego lokalne środowisko artystyczne nie mogło mu wybaczyć:

teatru nie można robić siłami lokalnymi. Kiedy pracowałem w Teatrze Wybrzeże, w Trójmieście mieszkało dwóch zawodowych reżyserów. Musiałem przywozić ludzi z całej Polski. Lokalni artyści poczuli się zdradzeni i konflikt powoli narastał [Święcicka 2015: 143].

Z powyższych uwag Nowaka wynika, że doskonale zdawał sobie sprawę z trudności, jakie wiążą się z angażowaniem twórców z zewnątrz, ale jednocześnie przedkładał artystyczne korzyści wynikające z takiej współpracy nad ewentualne problemy. $\mathrm{W}$ ten sposób po raz kolejny zaświadczał o swoim uwikłaniu w misyjność teatru, często kolidującą z czynnikiem ekonomicznym, co dla zarządcy teatru tworzy sytuację patową. Jednak, jak zauważa sam Nowak: „Zarządzanie to nie czary-mary. Po 1989 roku zaczęliśmy uważać, że menadżer to jakaś święta postać, kapłan, który posiadł wiedzę tajemną, a to są tak naprawdę dość proste zależności” [Święcicka 
2015: 138]. Tym stwierdzeniem Nowak wydaje się uderzać w sedno problemu zarządczego w polskich teatrach, który dotyczy wspomnianej wyżej w odniesieniu do paradygmatu platońskiego, hegemonii menedżeryzmu, rozwijającej się w polskich instytucjach publicznych od upadku komunizmu do dziś. W tym kontekście Jerzy Łysiński wskazuje na zbytnią wiarę „w uniwersalizm metod nowoczesnego managementu" [2012: 101], reprezentowaną przez polskich decydentów, którzy bezrefleksyjnie usiłują implementować wolnorynkowe rozwiązania amerykańskie do zarządzania kulturą w Polsce³.

Ta dychotomia w podejściu do zarządzania kulturą, odzwierciedlająca zderzenie paradygmatów arystotelesowskiego i platońskiego, wydaje się do dnia dzisiejszego stanowić oś sporu między decydentami a artystami w obszarze działań artystycznych finansowanych z funduszy publicznych. Rozważając dominujący status instrumentalnego paradygmatu platońskiego w Polsce („ofensywy menadżerskiej”), Łysiński przywołuje zasadniczy dokument formatywny w tym zakresie, a mianowicie raport Jerzego Hausnera Kultura $w$ kryzysie czy kryzys w kulturze. W dokumencie tym, usiłującym zdiagnozować kryzys zarządczy w polskich instytucjach kultury, całkowicie brakuje, według Łysińskiego, refleksji nad autoteliczną wartością kultury, natomiast dominuje refleksja ekonomiczna. Takie instrumentalne podejście do zasobów kultury, traktowanej jako „katalizator korzyści ekonomicznych”, Hausner powiela w Uzupetnieniu Narodowej Strategii Kultury na lata 2004-2020, gdy stwierdza: „W Polsce potrzebne jest nowe rozumienie kultury, traktowanej jako długoterminowa inwestycja ekonomiczna, przynosząca dochody i miejsca pracy" [za: Łysiński 2012: 104]. Wobec takiego podejścia, bezkrytycznie akceptowanego i wdrażanego przez decydentów, podejście arystotelesowskie wydaje się propozycją biegunowo odmienną i to w niej model menedżersko-artystowsko-kapłański miałby rację bytu.

Mimo że cytowany wyżej Nowak wyraźnie sprzeciwia się „sakralizowaniu” funkcji menedżera w kulturze, to jednak elementy kapłańskie sam poniekąd wdrażał w swoim modelu zarządczym. Jego artystyczno-kapłański styl managementu wpisywał się w teorię twórczego chaosu:

Chociaż uporządkowanie rzeczywistości jest konieczne, skuteczny menadżer nie powinien dopuścić, aby stało się to jego obsesją. Powinien zdawać sobie sprawę, że wyzwolenie potencjału twórczego firmy jest dla niej szansą rozwoju. Podczas gdy kreatywność może zagrozić obecnym sposobom organizowania, jest również źródłem inwencji, innowacji i pasji życia. (...) kreatywność i inspiracja, przy równoczesnym istnieniu technicznej racjonalności, będą definiować efektywne przywództwo biznesowe [Hatch, Kostera, Koźmiński 2010: 25-27].

Doceniając w zarządzaniu rolę kreatywnego chaosu, rozpatrywanego poprzez metaforę artysty, autorzy uzupełniają ją o model kapłański, bazujący na wierze we

3 Por. Szulborska-Łukaszewicz [2016]. 
wspólne cele: „Czym jest wiara w kontekście biznesowym? Jest to wiara w przywódców oparta na założeniu, że ich cele są czyste. (...) organizacje mające u swych podstaw wiarę, przyciągają ludzi i jednoczą ich wokół communitas" [Hatch, Kostera, Koźmiński 2010: 193-197]. Tworzenie wspólnoty Nowak nieustannie akcentował jako swoje najważniejsze zadanie [Święcicka 2015: 140]. Głównym kryterium, jakie stosował jako dyrektor tworzący swój zespół reżyserski, było „interesujące świrostwo” [Święcicka 2015: 141], które sugeruje artystyczny potencjał i totalne zaangażowanie w projekt artystyczny. Dziedzina działalności teatralnej ma to do siebie, że tworzy wspólnoty ludzi, pracujących nad projektem w sposób totalny, często w układach pozaformalnych, poza określonym grafikiem prób ${ }^{4}$, w nieustannym kreatywnym napięciu, któremu towarzyszy „wysoki poziom mobilizacji”:

Rzadko można obserwować taki poziom poczucia wspólnoty okupionej w dodatku kolosalnym wysiłkiem. (...) Choć wydaje się, że ten rodzaj integracji wynika raczej z istoty twórczego procesu, jaki ma miejsce w teatrze, niż z określonych działań zarządzającego, jednak niewątpliwym zadaniem tego ostatniego jest wytrawne podtrzymywanie tej dynamiki, organizowanie otoczenia samego procesu, zapewnienie jego uczestnikom odpowiednich warunków, stworzenie swoistego parasola ochronnego nad całym przedsięwzięciem [Maciąg 2008: 47].

W wypadku Nowaka wydaje się, że udało się dyrektorowi wypracować efektywny model współpracy w tak zorganizowanej wspólnocie, jak ocenia Przemysław Gulda:

Obejmując teatr pięć lat temu, Maciej Nowak spotkał się ze skrajnymi reakcjami członków zespołu wobec swoich pomysłów i samej swej osoby. Dziś aktorzy stoją za nim murem, co jest znakomitym dowodem, jak daleko posunął się proces integracji środowiska skupionego wokół teatru [Gulda, Baran, Sowula 2005].

Sam Nowak przyznaje, co już wyżej zostało wspomniane, że chciał stworzyć swój własny zespół, chociaż w znaczącej mierze dotyczyło to reżyserów, zastany zespół aktorski został przez niego minimalnie zmieniony. W tej ostatniej kwestii Nowak zaprezentował bardzo racjonalne podejście, odzwierciedlające w pełni zintegrowaną postawę rozsądnego menedżera i zatroskanego kapłana:

Uważam, że myślenie o aktorstwie jako o zawodzie wędrownym jest pustym, romantycznym i anachronicznym mitem. Aktor to taki sam człowiek jak inni, ma kredyt, dzieci, musi gdzieś mieszkać. Nie da się ściągnąć artystów z zewnątrz, bo przecież brakuje mieszkań służbowych. Poza tym głęboko wierzę, że nie ma złych aktorów. Bywają aktorzy nieroztrenowani, niekochani,

4 „Praca poza godzinami wyznaczonymi do tego ustawowo jest w teatrze normą, zwłaszcza w końcowym okresie prób, i może trwać do późnej nocy, choć sprawia to czasem zasadnicze problemy z punktu widzenia prawnego" [Maciąg 2008: 47]. 
źle prowadzeni, zapomniani, ale nigdy nie są źli. Jeżeli okaże im się serce, wyznaczy właściwe zadania artystyczne, jeżeli utrzymuje się ich, tak jak sportowców, w dobrej formie, to zaczynają błyszczeć [Święcicka 2015: 139].

W idei stworzenia wspólnoty artystów skupionych na realizacji wspólnych celów, dla których dyrektor teatru będzie opiekunem, doradcą i protektorem, Nowak wydawał się po części realizować, mniej lub bardziej świadomie, koncepcję organizacji koleżeńskiej, którą Russell E. Palmer uznał za największe wyzwanie przywódcze [2010: 62]. Adaptując obserwację Palmera, wedle której organizację koleżeńską tworzą zazwyczaj wysokiej klasy profesjonaliści, których można określić „pracownikami wiedzy” [Palmer 2010: 62], ten typ organizacji w teatrze można określić mianem zespołu „pracowników talentu” z zastrzeżeniem, że dotyczy to wyłącznie zespołu artystycznego. W takiej formule współpracy każdy oczekuje, że będzie odgrywał znaczącą rolę w procesie decyzyjnym, który będzie miał charakter kolegialny. Dlatego największym wyzwaniem, stającym się czasami pułapką lidera, jest konieczność wsłuchiwania się w opinie partnerów. Nowak starał się balansować pomiędzy koleżeństwem a dyktaturą, gdy „kolegował się” z artystami, tworząc z nimi wspólnoty godne najlepszych tradycji artystycznej bohemy i oferując im swobodę i warunki realizacji ich projektów artystycznych, a jednocześnie twardą ręką autorytarnie zarządzał pionami techniczno-administracyjnymi (o czym dalej).

Koleżeński typ przywództwa jest o tyle efektywny, o ile istotnie wspiera pracowników i tworzy z nimi wspólną wizję oraz skłania ich do poszukiwań [Mrówka 2010: 37], co w kontekście produkcji artystycznej ma znaczenie zasadnicze. Analizując efektywność przywództwa w tak zakrojonych ramach, Rafał Mrówka [2010: 38] zwraca uwagę na kwestię charyzmy, co bezpośrednio wiąże się z zarządczymi modelami artysty i kapłana. Osobowość Nowaka miała niebagatelne znaczenie dla jego przywództwa. W organizacji koleżeńskiej, którą tworzył z artystami, był w istocie liderem z charyzmą. Koleżeński i transformacyjny (charyzmatyczny) sposób współpracy z artystami przyniósł zaskakujące efekty artystyczne, udowadniając tym samym skuteczność modelu przywódczego reprezentowanego przez Nowaka. Jak słusznie zauważa Łysiński: „Lokomotywami kultury w tym kontekście okazują się nie tyle profesjonalni menedżerowie, ile merytoryczni fachowcy artyści, obdarzeni wizją i charyzmą, którzy nie ulegają gustom i oczekiwaniom odbiorców kultury, lecz sami je tworzą" [2012: 108].

Zatem wzajemne zaufanie dyrektora i zespołu artystycznego, wspólnie tworzących, nie bez trudu, wspólnotę koleżeńską, stanowiło dla teatru podstawę jego artystycznego rozwoju. Nowak, obejmując stanowisko dyrektora Wybrzeża, w kontekście swojej wizji teatru zaproponował formułę „Teatru dla ludzi”, które to hasło w wymiarze realizacyjnym Mirosław Baran zdiagnozował jako „otwarcie gdańskiego teatru dla dramaturgii współczesnej, młodych twórców i «odkurzonych». adaptacji klasycznych tekstów" [Gdula et al. 2005]. Jacek Rakowiecki [2005] zauważa 
przy tym, że taka strategia estetyczna odniosła znaczący sukces. Istotnie, Nowak stworzył artystycznie nową jakość w Wybrzeżu, również poza sceną właściwą, gdy wyprowadzał spektakle poza budynek teatru, zgodnie z ideą „teatru dla ludzi”. Jak opisuje Jan Ciechowicz, Nowak obrał „kurs na przestrzenie pozateatralne, zdegradowane i depresyjne" [Ciechowicz 2019: 127]. Były to katakumby samego teatru, gdzie wystawiono Solo Andrzeja Stasiuka w reżyserii Agnieszki Olsten, zrujnowane hale Stoczni Gdańskiej, w których Jan Klata wyreżyserował swoją wersję Hamleta (H.), a Marjorie Hayes zrealizowała Happy End Bertolta Brechta. Nowak stworzył i realizował również projekt Szybkiego Teatru Miejskiego ${ }^{5}$, nawiązującego do bieżących spraw społecznych i tworzących spektakle-performanse grane w prywatnych mieszkaniach. Analizując fenomen zmiany wprowadzonej przez Nowaka, Joanna Puzyna-Chojka [2019: 77] przywołuje ideę teatru jako agory, proklamowanej przez Nowaka [2005], w którym „przywraca się sztuce związki z rzeczywistością” zgodnie ze strategią "teatru jak w mordę" (In-Yer-Face Theatre) [Puzyna-Chojka 2019: 73].

Niewątpliwy sukces artystyczny Wybrzeża, zaspokajający ambicje teatru awangardowego i zaangażowanego, jakkolwiek powodujący wysoki dyskomfort elit pragnących teatru środka, wiązał się ściśle z poczynaniami Nowaka w obszarze działań administracyjnych. Jako „rzeźnik z Targu Węglowego” i „krwiopijca z Zoli”, jak sam siebie określa, wyrzucił połowę pracowników:

Likwidowałem przede wszystkim stanowiska administracyjne i pracownie rzemieślnicze. W sytuacji, gdy jest tak ogromna podaż usług, nie widzę potrzeby utrzymywania pracowni w teatrach. (...) Zlikwidowałem więc wszystkie pracownie, poza krawiecką [Święcicka 2015: 138].

Jego celem, jak twierdzi, było zracjonalizowanie zatrudnienia - „ujawnienie potencjału aktorów”, którzy będąc na etacie, mało grywali, „, zmniejszenie biurokracji”, co równało się stanowczemu zredukowaniu etatów w pionie administracyjnym. Jednak najważniejszym ruchem administracyjnym Nowaka wydaje się wprowadzenie stanowiska kierownika produkcji, zatrudnianego jednorazowo do każdego spektaklu:

W polskim teatrze panują zazwyczaj bizantyńskie hierarchie. Każdy ruch musi być zatwierdzony przez dyrektora. (...) Starałem się od tego uciec, więc wprowadziłem funkcję człowieka, który odpowiada za cały proces powstawania spektaklu. Dysponuje budżetem, ogłasza przetargi, rekrutuje wykonawców [Święcicka 2015: 140].

Racjonalizując cykl produkcyjny, Nowak jednak zalegał z płatnościami dla zapraszanych producentów i artystów. Jak sam nonszalancko stwierdza: „opóźniałem płatności, jak mogłem”, co w perspektywie czasu musiało się zemścić w bilansie [2019].

5 Działalność STM pod przywództwem Nowaka szczegółowo omawia Małgorzata Jarmułowicz 
finansowego zadłużenia teatru, ale również w obniżonym kredycie zaufania artystów. Nowak szukał oszczędności, sprzedając niepotrzebne budynki należące do teatru i inwestując pozyskane środki w remonty scen i w nowe premiery. Taki sposób zarządzania Jacek Sieradzki porównał z wizerunkiem antreprenerów z lat dwudziestych ubiegłego wieku: „On ma w sobie coś z wizjonera i hochsztaplera jednocześnie. Przy głębokim poczuciu misji teatru, którego zadaniem jest poruszanie sumienia widzów i targanie ich trzewiami, zalegał z płaceniem artystom" [Berlińska 2005]. Misyjność swojego teatru dyrektor Nowak przedkładał nad swoje obowiązki zarządcze, co można rozumieć w kontekście pasji widza i krytyka, którym Nowak nigdy nie przestał być i co ujawniało się w imponującej swym rozmachem pracy teatru:

Graliśmy ponad pięćset spektakli w roku, robiliśmy latem festiwal naszego teatru i pokazywaliśmy wszystko, co mieliśmy w repertuarze, grając nawet cztery przedstawienia dziennie, zmieniliśmy porządek sezonu, dając przedstawienia latem, dostosowywaliśmy godziny spektakli do oczekiwań publiczności, grając w wakacje w Sopocie nawet o północy [Święcicka 2015: 142].

W tym szaleńczym sposobie realizowania misji teatru Nowak zatracił poczucie odpowiedzialności za ludzi, którzy tę misję pozwalali mu realizować. Paradoks tej sytuacji polegał na tym, że artyści kochali go za swobodę pracy artystycznej, jaką im oferował, a jednocześnie nie znosili go za jego nonszalanckie podejście do kwestii wynagradzania ich za pracę. Na korzyść Nowaka, w kontekście arystotelesowskiej misyjności, przemawia fakt, że kiedy miał wybór, czy płacić artystom, czy kontrahentom, zawsze najpierw płacił artystom, gdy jednak budżet się nie spinał, nie płacił nawet im: „Wiem, że można to oceniać w kategoriach moralnych - zapłacił aktorom, ale nie kontrahentom. Taką jednak miałem politykę, to mój wybór. Ponoszę tego konsekwencje - mówi Nowak" [Gulda et al. 2005].

Sukces artystyczny Wybrzeża pod przywództwem Nowaka miał zatem swoje ciemne strony, wynikające, jak się wydaje, z niefrasobliwości zarządczej dyrektora, a raczej z nieumiejętnego balansowania między trzema modelami przywództwa. Chcąc zorganizować wspólnotę koleżeńską, mającą pod jego parasolem ochronnym realizować nowatorskie projekty artystyczne, w czym wypełniał model kapłańsko-artystowski i co mu się udało, Nowak jednocześnie próbował sięgać po radykalne rozwiązania racjonalnego menadżera, które pozwalały mu na pozyskiwanie funduszy i oszczędności, ale które generowały kosztowne konflikty.

Podsumowując, w obszarze współpracy dyrektora z zespołem Nowak osiągnął niebywały sukces w wymiarze artystycznym, okupiony jednak wieloma konfliktami, wynikającymi z braku klarownych rozliczeń finansowych $\mathrm{z}$ artystami oraz z radykalnych cięć etatów w pionach pomocniczych. Specyfika artystycznej pracy teatru, nawet w paradygmacie arystotelesowskim, wymaga wsparcia techniczno-administracyjnego i często wiąże się z tworzeniem relacji w poczuciu misyjności. Obecność w teatrze stałych pracowni rzemieślniczych, których pracownicy w równie oddany sposób 
poświęcą swój czas i umiejętności dla realizacji projektu artystycznego, wydaje się dla pracy teatru kluczowa. Ich likwidacja i zawierzenie outsourcingowi przez Nowaka z perspektywy czasu okazała się błędem. Natomiast zaopiekowanie się zespołem aktorskim i potraktowanie artystów sceny jako pracowników, o których trzeba dbać i którym trzeba zapewnić, tak jak sportowcom, najlepsze warunki treningu, jest podejściem zarządczym, dającym, jak w przypadku Nowaka, pozytywne efekty zarówno artystyczne, jak i ekonomiczne. Wspieranie zespołu stałego teatru mało wówczas znanymi artystami reżyserami z zewnątrz było zabiegiem ambiwalentnym, w którym jednak aktywa znacząco przewyższały pasywa. Stały zespół aktorski pozostawał w nieustannym napięciu związanym z coraz to nowymi wyzwaniami artystycznymi, dzięki czemu mógł wszechstronnie rozwijać swoje talenty. Niemniej dyrektor zmagał się z nowymi pracownikami sezonowymi (reżyserami), którzy w procesie swojej indywidualnej produkcji hegemonizowali pracę w projekcie, nie zważając na całościowy bilans działalności teatru w szerszej perspektywie. Wszystkie te problemy stanowiły jednak, jak można sądzić, normalne zjawiska momentu rodzenia się wizji przywódczej i jej sprawdzania w doświadczeniu. Być może, gdyby pozwolono Nowakowi kontynuować obraną strategię, opracowałby on model umiejętnie balansujący między misyjnością teatru a ekonomią jego istnienia.

W tym kontekście należy przyjrzeć się drugiemu obszarowi krytycznemu w zarządzaniu teatrem, który w przypadku Nowaka stał się czynnikiem zapalnym konfliktu i doprowadził do usunięcia go z Teatru Wybrzeże. Chodzi o relację dyrektora $\mathrm{z}$ lokalnym środowiskiem polityczno-biznesowym. Zazwyczaj bowiem to politycy samorządowi powołują, na podstawie konkursu lub bez niego, dyrektora teatru publicznego, decydują o dotacjach na działalność teatru i mają prawo tę działalność kontrolować pod względem finansowym. Poza tym lokalny biznes postrzegany jest jako potencjalny sponsor teatru, budujący w ten sposób swój wizerunek odpowiedzialnego partnera kultury, zaangażowanego w jej rozwój w wymiarze lokalnym. Analizując wspomniany raport Hausnera, Łysiński wskazuje na zawartą w nim słuszną uwagę dotyczącą znaczenia czynników politycznych w zarządzaniu publicznymi instytucjami kultury. Hausner wyraźnie sugeruje, że instytucje muszą zostać uwolnione od „politycznego paternalizmu i urzędniczej uznaniowości” [za: Łysiński 2012: 103]. Jednak proponowane zmiany w tym zakresie nie pozwalają, na co wskazuje praktyka, na pełne odpolitycznienie teatrów. Aktualne wzmożenie ideologiczne, promowane przez politykę kulturalną obecnego rządu, wyraźnie rozbudowuje rolę czynnika politycznego, będącego nośnikiem promowanej ideologii, w obsadzie stanowisk zarządczych w instytucjach kultury. Przykłady Teatru Polskiego we Wrocławiu i Narodowego Starego Teatru w Krakowie wyraźnie potwierdzają tezę o ideologicznym interwencjonizmie państwowym w teatrach publicznych.

Nowak został dyrektorem Wybrzeża po nierozstrzygniętym konkursie [Święcicka 2015: 146]. To okazało się problematyczne z uwagi na outsiderski status Nowaka 
w Gdańsku. On sam podkreśla, jak istotne znaczenia dla pracy dyrektora teatru ma jego zanurzenie w lokalny układ towarzyski, mówi:

Mam głębokie przekonanie, że gdybym wszedł w to środowisko, gdybym był dobrze ze wszystkimi ustawiony, to pewnie nic by się nie stało. Tylko ja, i tu być może jest moja głupota, tego kosztu nie chciałem ponieść, nie chciałem wchodzić w żadne układy lokalne [Święcicka 2015: 147].

Tu Nowak wskazuje oczywiście na jeden z powodów swojego odwołania ze stanowiska w 2006 roku, który upatrywał właśnie w braku bliższych kontaktów towarzysko-biznesowych z lokalną elitą, co może być uznane za argument emocjonalny, co jednak nie wydaje się tak znowu odległe od ogólnej praktyki wsobnego obsadzania stanowisk dyrektorskich w ogóle. Desant Nowaka w Wybrzeżu był w tym kontekście gestem rewolucyjnym ówczesnego marszałka województwa pomorskiego, Jana Kozłowskiego, który w czasie kolejnych sezonów pod dyrekcją Nowaka ofiarowywał mu kolejne kredyty zaufania, jak wskazuje jeden z komentatorów, Sławomir Sowula:

Marszałek województwa Jan Kozłowski, prowadząc nadzór nad Maciejem Nowakiem, dyrektorem teatru Wybrzeże, długo zachowywał się po chrześcijańsku. Kiedy Nowak przychodził z pustymi kieszeniami niczym syn marnotrawny, Kozłowski darowywał mu winy, wyprawiał na jego cześć „ucztę”. I to był błąd. Gdyby przydzielił mu bonę - dobrego menedżera od finansów - być może nie zgubiłby swojego ulubieńca. Marszałek nie wyznaczył żadnej bony, która nadzorowałaby finanse, a sam Nowak jej nie szukał [Gulda et al. 2005].

\section{Z kolei Łukasz Drewniak zauważa:}

Liberalno-polityczny profil teatru spodobał się widzom i recenzentom, zdenerwował jednak lokalne władze, które dotują teatr. „Oczekują oni - tłumaczy już sam Nowak - że w Gdańsku będzie działał teatr w typie warszawskiego Teatru Kwadrat czy Ateneum pomagający widzom z klasy średniej odbębnić kulturalny rytual” [Drewniak 2005].

Zatem, kwestia przynależności do lokalnego układu biznesowo-politycznego, współfinansującego działalność teatru, wiąże się bezpośrednio również z linią repertuarową teatru i sposobem jej realizacji.

Przychodząc do Wybrzeża, Nowak zastał „długi, konflikty i teatr praktycznie niegrający spektakli" [Święcicka 2015: 136], co wobec nieufności lokalnej elity, jak również samego zespołu teatru tworzyło sytuację wyjściową wyjątkowo niekomfortową. Nowak miał zadanie o tyle trudniejsze, że pełnił połączoną funkcję dyrektora administracyjnego i artystycznego, czyli odpowiadał za wszystko. Jednak sam Nowak uznał taki układ za korzystny: 
Połączenie tych funkcji wydaje mi się właściwe i naturalne, bo jednak głównym celem teatru jest działalność artystyczna. Jeżeli dyrektor artystyczny ma za partnera naczelnego, który nie funkcjonuje w świecie artystycznym, jeżeli ostatnie zdanie należy do osoby zajmującej się tylko kwestiami finansowymi, to zwykle nic z tego wychodzi, za to dużo jest poważnych konfliktów [Święcicka 2015: 137].

Jednak w modelu arystotelesowskim, który zarządcę teatru ustanawia w funkcji służebnej wobec projektu artystycznego, dwudzielny model zarządczy wydaje się rozsądną propozycją. Jak sugerował cytowany wyżej Sowula, marszałek województwa powinien był przydzielić Nowakowi „bonę od finansów”, człowieka, który nadzorowałby budżet teatru i informował dyrektora artystycznego o finansowych możliwościach udźwignięcia planów artystycznych. Hierarchia modelu arystotelesowskiego ustanawiałaby w tym kontekście decyzyjność dyrektora artystycznego na poziomie najwyższym, a dyrektor finansowy pełniłby funkcję doradczą i dyscyplinującą. Nowak ma rację, mówiąc, że głównym celem teatru jest działalność artystyczna, z czego wynika oczywista konstatacja o naczelności dyrektora artystycznego. Jednak taki lider, $\mathrm{z}$ artystyczną wizją i rozpoznanymi strategiami jej realizacji, jakie proponował i realizował Nowak, musi, jak się wydaje, posiadać wsparcie doradcze w kwestiach zarządzania finansami, szczególnie w przypadku, gdy są to finanse publiczne, podlegające rygorom kontrolnym instytucji publicznych.

\section{Dyrektor odchodzi...}

Powody ostatecznego odwołania Nowaka ze stanowiska dyrektora Teatru Wybrzeże wcale nie są tak oczywiste i możliwe do jednoznacznego zidentyfikowania. Awantura, jaką spowodowała decyzja marszałka Kozłowskiego, trwała ponad rok, wywołując skrajne emocje i angażując masy ludzkie produkujące listy, petycje, komentarze, analizy. Sam Nowak, usiłując dociec przyczyny swojego odwołania, przywołuje przypuszczenie natury obyczajowej, czyli oskarżenie o „pedalski teatr Nowaka”. Kontynuując ten wątek, Nowak wskazuje na swój personalny konflikt z ówczesnym posłem z Pomorza, Aramem Rybickim, który głośno i nieustannie głosił, że „w kaszubskim konserwatywnym Gdańsku taka osoba jak Maciej Nowak nie może być dyrektorem teatru" [Święcicka 2015: 144]. Nowak wspomina, że to właśnie ten polityk zainicjował obyczajowy atak na niego, co pośrednio potwierdził mu marszałek Kozłowski, mówiąc, że „naciski środowiska [w sprawie jego odwołania - M.B.] są bardzo mocne" [Święcicka 2015: 145]. Jednak by móc go zwolnić z powodów w miarę poważnych, rozpoczęto działania mające celowo doprowadzić do zadłużenia teatru. Nowak wspomina: 
Sytuacja finansowa była wciąż trudna. Dług rósł, malały dotacje, bo władza coraz bardziej okazywała, że nie ma tam dla mnie miejsca. Chcieli mnie zmusić do szukania sponsorów, komercjalizacji teatru. Nikt nie patrzył, jak teatr sobie radzi artystycznie, oceniano tylko pod kątem finansowym. Ze wszystkich wychodził surowy tatuś, który kiwał palcem i pouczał. Nikt nie chciał wiedzieć o warunkach, w jakich pracuję, o tym, że dotacja nie pozwala nawet na pokrycie kosztów stałych, mimo że tak stanowi ustawa o prowadzeniu działalności kulturalnej, więc samorząd narusza prawo [Święcicka 2015: 143].

Kiedy ostatecznie było już wiadomo, że Nowak musi odejść, zespół teatru podniósł bunt przeciwko decyzji marszałka i zorganizował w Ratuszu Staromiejskim spotkanie z władzami i przedstawicielami trójmiejskiej elity, na które przybyło też wielu przedstawicieli środowiska teatralnego z Polski. Jednak na tym spotkaniu przedstawiciele elit nie umieli sformułować konkretnych zarzutów i Nowak pozostał na stanowisku jeszcze przez rok [Święcicka 2015: 145-146]. Ów rok (sezon 2005/2006) był jednak karuzelą kontroli finansowych oraz istną hucpą w kontekście coraz to na nowo rozpisywanych i oprotestowywanych konkursów na nowego dyrektora, do których Nowak nie mógł przystąpić, choć chciał, ze względów formalnych - wymagano wyższego wykształcenia, którego Nowak nie miał. Postawiono mu nawet zarzut niegospodarności, ale ostatecznie po przeprowadzonym śledztwie sprawę umorzono $^{6}$. Oficjalnie jednak nadal wskazuje się na zadłużenie teatru jako przyczynę jego odwołania. Szczegółowo próbuje ten problem zreferować Sowula [Gulda et al. 2005], ale z jego obliczeń wynika tylko tyle, że Nowak zbyt ufnie podchodził do obietnic marszałka i ministerstwa w kwestii wysokości obiecanych dotacji, które ostatecznie albo wcale nie trafiały do Wybrzeża, albo były znacznie mniejsze. Sowula przyznaje również, że Nowak był bardzo efektywny w zdobywaniu funduszy poza dotacjami, jednak nie potrafił nimi właściwie dysponować ${ }^{7}$, co ponownie prowadzi do refleksji nad koniecznością wspomagania działalności dyrektora artystycznego przez doradcę finansowego. Z lektury tekstów zebranych na portalu e-teatr oraz na podstawie jego własnych refleksji można wywnioskować, że stał się po prostu persona non grata ze względów ideologicznych oraz z powodu swojej niesterowalności.

6 Por. opinię samego Nowaka: „Mojemu następcy zostawiłem operacyjne zadłużenie rzędu dwustu tysięcy. Na pierwszym zebraniu z aktorami powiedział, że słyszał o niebotycznych długach i jest zaskoczony w miarę stabilną sytuacją finansową" [Święcicka 2015: 146].

7 „Na plus Nowaka trzeba zaliczyć, że nie wyciągał ręki tylko po dotacje. Sprzedał za ponad $6 \mathrm{mln}$ zł zbędne budynki teatru. Znalazł najemców na kilka lokali. To ożywiło tę część miasta. Powstało kilka barów i restauracji, za kilkanaście miesięcy powstanie hotel. Te nadzwyczajne przychody poszły na remont teatru, ale w części też zostały przejedzone" [Gulda et al. 2005]. 


\section{Konkluzje}

Dyrekcja Nowaka w Teatrze Wybrzeże w odbiorze środowiska artystycznego uchodzi za fenomen niemal nie do powtórzenia, gdy upadająca scena nagle rozkwita w trybie rewolucyjnym, siejąc twórczy ferment na cały kraj. Nawet kontestatorzy linii repertuarowej Nowaka przyznają, że to on odkrył lub pozwolił zaistnieć Michałowi Zadarze, Janowi Klacie, Monice Strzępce, Pawłowi Demirskiemu, Grzegorzowi Wiśniewskiemu i wielu innym, obecnie dominującym w teatrze progresywnym. Jak sam twierdzi, odszedł w momencie artystycznego tryumfu Wybrzeża [Święcicka 2015: 147]. W liście otwartym, który opublikował w czasie awantury w Wybrzeżu, melancholijnie, ale i trzeźwo stwierdza: „Dyrektorzy przychodzą i odchodzą, a władze samorządowe mają prawo do decydowania o losie podległych im instytucji. To musi pozostać poza dyskusją" [Nowak 2005]. Sam swoje dyrektorowanie w Wybrzeżu formował „rozpoznaniem bojem” [Dobrowolski 2018], bez wstępnych założeń teoretycznych, z elastycznym nastawieniem do zastanych warunków możliwości. Realizując stricte arystotelesowski typ zarządzania instytucją kultury, z poczuciem misji i niezachwianą wiarą w nadrzędną rolę sztuki, nie bez potknięć, wynikających z własnej pychy [Drewniak 2005], ale warunkowanych głównie okolicznościami zewnętrznymi, Nowak implementował Pięć Naczelnych Zasad Wzorowego Przywództwa, czyli wskazywał właściwą drogę, rozbudzał wspólną wizję, nie bał się zmian, pozwolił działać innym, motywował i wspierał [Kouzes, Posner 2010: 13]. Prezentował zatem model idealnego przywódcy, któremu jednak zabrakło wsparcia doradczego w zakresie finansów. To spostrzeżenie, w odniesieniu do optymalnego modelu zarządczego w teatrze, prowadzi do konstatacji o pozytywnym charakterze dwudzielnego modelu zarządczego, w którym to dyrektor artystyczny miałby głos decydujący, a zespół finansowy pełniłby funkcje doradcze, zgodnie z założeniami paradygmatu arystotelesowskiego. Interwencjonizm polityczny i ideologiczny, który doprowadził do usunięcia Nowaka ze stanowiska, jest aberracją, która w sposób istotny, do dnia dzisiejszego, niszczy wszelkie próby wypracowywania optymalnego modelu zarządczego dla teatru.

\section{Bibliografia}

Arystoteles (1988), O duszy, tłum. P. Siwek, Warszawa: Państwowe Wydawnictwo Naukowe. Bendixen P. (2008), O filozoficznych fundamentach teorii zarzadzania kultura, „Culture Management / Zarządzanie Kulturą", t. 1, s. 219-226.

Berlińska A. (2005), Nowak odchodzi, „Ozon”, nr 11, http://www.e-teatr.pl/pl/artykuly/14099. html?josso_assertion_id=19A2D565AF1139E1 [odczyt: 12.11.2019]. 
Ciechowicz J. (2019), Teatr dla ludzi (w przestrzeniach niekonwencjonalnych), [w:] J. Puzyna-Chojka, K. Kręglewska, B. Świąder-Puchowska (red.), Teatr Wybrzeże w latach 1996-2016, Gdańsk: Wydawnictwo Uniwersytetu Gdańskiego, s. 125-133.

Dobrowolski P. (2018), Spłacam swój dług. Wywiad Piotra Dobrowolskiego z Maciejem Nowakiem, teatralny.pl, http://www.e-teatr.pl/pl/artykuly/15875.html [2.12.2019].

Drewniak Ł. (2005), Obywatel Nowak, „Foyer”, nr 15, http://www.e-teatr.pl/pl/artykuly/15830. html [odczyt: 25.10.2019].

Gulda P., Baran M., Sowula S. (2005), Trzy odsłony sprawy Nowaka, „Gazeta Wyborcza - Trójmiasto", nr 158, http://www.e-teatr.pl/pl/artykuly/14379.html [odczyt: 25.10.2019].

Hatch M.J., Kostera M., Koźmiński A.K. (2010), Trzy oblicza przywództwa. Menedżer, artysta, kapłan, Warszawa: Wydawnictwa Akademickie i Profesjonalne.

Jarmułowicz M. (2019), W pogoni za prawdą. Szybki Teatr Miejski, [w:] J. Puzyna-Chojka, K. Kręglewska, B. Świąder-Puchowska (red.), Teatr Wybrzeże w latach 1996-2016, Gdańsk: Wydawnictwo Uniwersytetu Gdańskiego, s. 134-150.

Kasza J. (2017), Zarządzanie kulturq a hegemonia dyskursu ekonomicznego - analiza przypadku: Teatr Studio w Warszawie, „Zarządzanie w Kulturze”, t. 18, z. 3, s. 443-466.

Kouzes J.M., Posner B.Z. (2010), Przywództwo i jego wyzwania, tłum. A.E. Chudzio, Kraków: Wydawnictwo Uniwersytetu Jagiellońskiego.

Łysiński J. (2012), Paradygmaty współczesnego zarządzania kulturą w Polsce, „Zeszyty Naukowe Małopolskiej Wyższej Szkoły Ekonomicznej w Tarnowie”, t. 20, nr 1, s. 99-111.

Maciąg R. (2008), Spektakl teatralny jako przedmiot zarzadzania: konsekwencje teoretycznych sporów w interpretacji statusu ontologicznego postaci teatralnej i przedstawienia teatralnego dla konstrukcji modelu organizacyjnego teatru Giepa Hagoorta, „Zarządzanie w Kulturze”, t. 9, s. 43-57.

Mrówka R. (2010), Przywództwo w organizacjach. Analiza najlepszych praktyk, Warszawa: Wolters Kluwer business.

Nowak M. (2004), My, czyli nowy teatr, „Notatnik Teatralny”, nr 36, http://www.e-teatr.pl/pl/ artykuly/8314.html [odczyt: 25.11.2019].

Nowak M. (2005), List otwarty dyrektora Teatru Wybrzeże, e-teatr.pl, http://www.e-teatr.pl/pl/ artykuly/14100.html [odczyt: 15.11.2019].

Palmer R.E. (2010), Przywództwo doskonałe, tłum. D. Wąsik, Warszawa: Wolters Kluwer business. Platon (1958), Protagoras, tłum. W. Witwicki, Warszawa: Państwowe Wydawnictwo Naukowe. Puzyna-Chojka J. (2019), Trans/formacja. Teatr Wybrzeże na tle przemian strukturalnych i estetycznych przełomu wieków" [w:] J. Puzyna-Chojka, K. Kręglewska, B. Świąder-Puchowska (red.), Teatr Wybrzeże w latach 1996-2016, Gdańsk: Wydawnictwo Uniwersytetu Gdańskiego, s. 58-77. Rakowiecki J. (2005), Niezwykła, ale prawdziwa historia Macieja Nowaka, artysty teatralnego, „Foyer”, nr 15, http://www.e-teatr.pl/pl/artykuly/15875.html [odczyt: 10.10.2019].

Szulborska-Łukaszewicz J. (2016), Trends in Cultural Policy and Culture Management in Poland (1989-2014) (II), „Zarządzanie w Kulturze”, t. 17, z. 2, s. 107-124.

Święcicka O. (2015), Mnie nie ma. Rozmowa z Maciejem Nowakiem, Wołowiec: Czarne. Trzeciak H. (2011), Ekonomika teatru, Warszawa: Instytut Teatralny im. Zbigniewa Raszewskiego. 